\title{
Management of advanced corneal ectasias
}

\author{
Prafulla K Maharana, ${ }^{1}$ Aditi Dubey, ${ }^{1}$ Vishal Jhanji, ${ }^{2}$ Namrata Sharma, ${ }^{3}$ Sujata Das, ${ }^{4}$ \\ Rasik B Vajpayee ${ }^{5}$
}

1 Department of

Ophthalmology, All India Institute of Medical Sciences, Bhopal, India

${ }^{2}$ Department of Ophthalmology

and Visual Sciences, The

Chinese University of Hong

Kong, Hong Kong

${ }^{3}$ Dr. Rajendra Prasad Centre

for Ophthalmic Sciences,

All India Institute of Medical

Sciences, New Delhi, India

${ }^{4}$ L.V.Prasad Eye Institute,

Bhubaneswar, India

${ }^{5}$ Vision Eye Institute, Royal

Victorian Eye and Ear Hospital,

North West Academic Centre,

University of Melbourne,

Melbourne, Australia

\section{Correspondence to}

Professor Rasik B Vajpayee,

Vision Eye Institute, Royal

Victorian Eye and Ear Hospital,

North West Academic Centre,

University of Melbourne,

Melbourne, VIC 3002,

Australia; rasikv@unimelb.edu. $\mathrm{au}$

Received 20 April 2015

Revised 10 June 2015

Accepted 21 July 2015

Published Online First

20 August 2015
CrossMark

\author{
To cite: Maharana PK, \\ Dubey $A$, Jhanji $V$, et al. Br J \\ Ophthalmol 2016;100 \\ 34-40.
}

\section{ABSTRACT}

Corneal ectasias include a group of disorders characterised by progressive thinning, bulging and distortion of the cornea. Keratoconus is the most common disease in this group. Other manifestations include pellucid marginal degeneration, Terrien's marginal degeneration, keratoglobus and ectasias following surgery. Advanced ectasias usually present with loss of vision due to high irregular astigmatism. Management of these disorders is difficult due to the peripheral location of ectasia and associated severe corneal thinning. Newer contact lenses such as scleral lenses are helpful in a selected group of patients. A majority of these cases requires surgical intervention. This review provides an update on the current treatment modalities available for management of advanced corneal ectasias.

\section{INTRODUCTION}

The term corneal ectasias includes a group of conditions characterised by progressive thinning, bulging and distortion of the cornea. The commonly encountered ectatic disorders of cornea are keratoconus, pellucid marginal degeneration (PMD), Terrien's marginal degeneration (TMD), keratoglobus, postrefractive surgery ectasia (photorefractive keratectomy (PRK), radial keratectomy (RK) and laser in situ keratomileusis (LASIK)) and postkeratoplasty ectasia. ${ }^{1}$ The management of these cases is a major challenge for corneal surgeons because it affects visual acuity (VA) and decreases corneal strength. Thus the aim of the treatment in such cases includes improving VA and simultaneously providing tectonic support to the cornea. ${ }^{2}$

The management of early cornea ectasia is well established in literature, but the management of advanced corneal ectasias (ACEs) is still challenging since there are no definitive guidelines. Newer generation contact lenses (CL) may be useful in some of these cases, but a majority of these cases require surgical intervention. Penetrating keratoplasty (PKP) was the most commonly performed surgical procedure for such disorders in the past. However PKP is associated with a higher risk of complications such as corneal neovascularisation, graft rejection, induced astigmatism and glaucoma. ${ }^{3-5}$ Newer surgical techniques and modification of existing techniques over the last decade have minimised these limitations..$^{3-5}$ This article provides an update on the currently available treatment options for advanced corneal ectasia.

\section{DEFINITION}

The term advanced corneal ectasia is well defined in cases with keratoconus, but in other disorders such as PMD or TMD there are no defining criteria. Keratoconus is a non-inflammatory, bilateral corneal ectasia characterised by gradual thinning and protrusion of the cornea. ${ }^{4}$ The severity of the keratoconus was classified by Krumeich et al based on the mean keratometry readings on the anterior map of corneal topography, thickness at the thinnest location and the refractive error of the patient. ${ }^{6}$ According to this classification advanced keratoconus is considered as: keratometric reading $(\mathrm{Km})$ of $>55 \mathrm{D}$, refraction not measurable, central corneal scarring and corneal thickness $<200 \mu \mathrm{m}$ at the thinnest location. ${ }^{6}$ Buxton et al have defined advanced keratoconus as $\mathrm{Km}>52.00 \mathrm{D}$ but $<62 \mathrm{D}$ and severe keratoconus as $\mathrm{Km}>62.00 \mathrm{D}^{7}{ }^{7} \mathrm{PMD}$ is a bilateral, peripheral corneal ectatic disorder characterised by a band of thinning cornea $1-2 \mathrm{~mm}$ in width, typically the inferior cornea, extending from the 4 o'clock position to the 8 o'clock position. ${ }^{8} 9$ TMD is a bilateral peripheral corneal ectasia primarily affecting the superior cornea and characterised by high irregular astigmatism, thinning, inflammation, vascularisation and lipid deposition. ${ }^{10}$ Keratoglobus is a bilateral corneal ectatic disorder characterised by globular protrusion of the cornea due to generalised thinning, most marked in the periphery. It is usually present at birth and these corneas are prone to rupture after minimal trauma or even spontaneously. ${ }^{11}$ Corneal ectasia after surgery is characterised by progressive corneal thinning and irregular astigmatism. ${ }^{12}$ These changes have been described as secondary keratoconus by some authors. It has been reported in literature following LASIK, RK, PRK, PKP and deep anterior lamellar keratoplasty (DALK). ${ }^{13-19}$

\section{CLINICAL FEATURES}

Patients with advanced corneal ectasia present with distorted VA due to irregular astigmatism or corneal scarring. ${ }^{20}$ Most of the patients are already diagnosed at an early stage and gradually progress to an advanced stage following natural course of the disease or failure to halt the progression. The important clinical features with differentiating points are given in table $1 .{ }^{20}$

\section{INVESTIGATIONS}

Investigations are required for diagnosis, documentation of progression and planning of treatment.

\section{Pachymetry}

Corneal thickness measurement is important for the diagnosis and management of advanced corneal ectasia. Ultrasonic pachymetry remains the standard method for corneal thickness measurement. ${ }^{21} \mathrm{~A}$ nine point pachymetry should be done to map the entire cornea. The advantage is that it is simple and cost-effective, but the limitation is the risk of 
Table 1 Differentiating clinical features of corneal ectasias ${ }^{20}$

\begin{tabular}{|c|c|c|c|c|}
\hline Characteristics & Keratoconus & PMD & Keratoglobus & TMD \\
\hline Frequency & Most common & Less common & Rare & Rare \\
\hline Laterality & Usually bilateral & Bilateral & Bilateral & Usually bilateral \\
\hline Age at onset & Puberty & $20-40$ years & Usually at birth & $20-40$ years \\
\hline Thinning & Inferior paracentral & Inferior band 1-2 mm wide & Maximum in periphery & Superior cornea \\
\hline Protrusion & Thinnest at apex & Superior to band of thinning & Generalised & None \\
\hline Iron line & Fleischer ring & Sometimes & None & None \\
\hline Scarring & Common & Only after hydrops & Mild & $\begin{array}{l}\text { Less common (vascularisation } \\
\text { and lipid deposition seen) }\end{array}$ \\
\hline Striae & Common & Sometimes & Sometimes & None \\
\hline
\end{tabular}

PMD, pellucid marginal degeneration; TMD, Terrien's marginal degeneration.

corneal injury and transmission of infection as it is a contact procedure. $^{21} 22$ Newer investigational modalities like Scheimpflug imaging and anterior segment optical coherence tomography (ASOCT) are more accurate non-contact methods and are extremely helpful in these cases. ${ }^{23} 24$

\section{Corneal topography}

Various tools such as videokeratography (VKG, Placido disc based principle), Orbscan II (slit-scanning) and Pentacam (Scheimpflug imaging) can be used for topographical assessment of the cornea. VKG is useful for surface topography but a major limitation is that peripheral corneal and posterior curvature mapping is either not possible or is less accurate in cases with advanced ectasia. ${ }^{21-23}$ Compared with VKG, Orbscan II gives a better pachymetric map, but repeatability and posterior curvature mapping is still less than accurate..$^{21-23}$ Pentacam has the advantage of providing precise corneal thickness, and posterior elevation with good repeatability. ${ }^{23}$ Hence Pentacam is the preferred modality by most of the corneal surgeons.

\section{Anterior segment optical coherence tomography}

The newer generation ASOCT provides real-time highresolution cross-sectional mapping across any meridian of choice in ectatic corneal disorders, hence it is an extremely useful tool. ${ }^{24}$ In addition to corneal thickness values it gives details about anterior segment structures. It is a useful postoperative tool for evaluating corneal graft, graft host junction and graft interface. ${ }^{25}$ ASOCT is also useful for the diagnosis and management of complications such as corneal hydrops. ${ }^{26} 27$

\section{COMPLICATIONS}

Complications of ACE include corneal hydrops, corneal perforation and corneal vascularisation. ${ }^{20}$ Corneal hydrops is characterised by corneal oedema due to seepage of aqueous humour through a tear in the Descemet's membrane (DM). ${ }^{1}$ Spontaneous corneal perforation or perforation after trivial trauma is commonly seen in cases with keratoglobus and TMD. ${ }^{10}$

Corneal hydrops has been reported with keratoconus, PMD, TMD, keratoglobus and post-LASIK ectasia. ${ }^{1}$ A tear in DM, with subsequent seepage of aqueous humour into the corneal stroma is the underlying mechanism in all cases. If not treated, resolution usually takes a long time and occurs by endothelial sliding over a period of 2-4 months. ${ }^{1}$ Medical management consists of topical hypertonic drops, topical steroids, prophylactic antibiotic drops and antiglaucoma medications. However persistent oedema can cause complications such as corneal neovascularisation, infection and corneal perforation. Surgical intervention is often performed to shorten the duration of the disease. ${ }^{127}$ Intracameral injection of air/isoexpansile gases is the most commonly performed procedure. In the presence of a large DM detachment or stromal clefts, ASOCT guided intrastromal drainage with stab incisions, compressive sutures and even penetrating keratoplasty may have to be performed. ${ }^{127}$

\section{MANAGEMENT}

Management of ACE is challenging. Various treatment options, non-surgical and surgical have been tried, which are briefly discussed below.

\section{Non-surgical management}

Spectacle correction in ACE has no or minimal role. These may be prescribed to selected patients who are intolerant to CL and are not willing to undergo any surgery. Corneal rigid gas permeable (RGP) CL are hard CL that have the advantage of masking corneal irregularities, thus providing a regular anterior refractive surface. These are often the initial lenses to try in cases of corneal ectasia. RGP lenses usually rest on the apex of the cone; so to fit RGP lenses in keratoconus, lenses that have a tricurve or more peripheral curves are used. There are three different types of CL fitting philosophies followed in fitting of these lenses; apical clearance, apical bearing or three point touch. In apical clearance fitting there is no bearing or touch in the apical area and the lens bearing in the periphery. Advantages are reduced risk of scarring, whorl keratopathy and erosions; the limitation is tightening at the periphery can hamper tear exchange and the edge of the lens can come into the visual axis, especially in cases with advanced ectasia. In apical bearing fitting, the optic zone of CL touches the apex of the cone. The advantage is better quality of vision but the problem is there can be heavy bearing on the cornea resulting in corneal scarring and intolerance over long-term use. In three point touch, fitting the lens bearing is shared between the apex and the midperipheral cornea which minimises the risk of apical scarring. These lenses provide good vision, better comfort and prolonged wearing time and are hence the most preferred type of lenses. ${ }^{28}$ Hybrid CL contain an RGP centre with a soft skirt. New-generation hybrid CL provide higher oxygen permeability and greater strength of the RGP/hydrogel junction. These lenses are fitted with no or minimal apical touch in the central cornea. The lenses can be fitted on cones of any severity but the problem with these lenses is they can cause hypoxia-related changes such as vascularisation and central corneal clouding. ${ }^{28}$ Newer generation CL such as Rose K, scleral lenses, prosthetic replacement of the ocular surface ecosystem (PROSE) and Boston ocular 
surface prosthesis (BOSP) have shown promise in some studies. $^{28-34}$

Rose $K$ Lenses (Rose K, Rose K2 XL and Rose K2 IC) are multicurve lenses with a small optical zone which snugly fits over the cone. The Rose-K CL provides greater comfort, better quality of vision and requires less chair time in cases with keratoconus. ${ }^{29} 3033$ The Rose K2 IC is a large diameter, intralimbal lens that can be used for large or oval cones. ${ }^{28}$ Scleral Lenses rest on the sclera and do not touch the cornea and limbus, leaving a clear area between the CL and the cornea. The advantages are good centration, stability and improved VA. The PROSE is a non-fenestrated scleral CL that is filled with fluid prior to insertion in the eye. Treatment has a high success rate when measured by the ability to achieve satisfactory fit and impact on VA. ${ }^{31}{ }^{34}$ PROSE treatment can be an alternative to PKP for patients with corneal ectasia who are CL intolerant. ${ }^{34}$ The BOSP is a fluid-filled scleral CL. These lenses rest on the sclera and do not touch the cornea. There is a constant pool of tears over the cornea, which acts as a liquid corneal bandage and avoids any friction between the posterior surface of the CL and the corneal apex. ${ }^{33}$ In addition these lenses mask corneal surface astigmatism and improve best-corrected VA. ${ }^{33}$ Thus these lenses are extremely useful in patients with advanced ectasia where the patients are intolerant to CL, or immediate surgery is not possible, or when surgery is refused by the patient. These lenses have also been found to be useful in various ocular surface disorders such as Stevens-Johnson syndrome, Sjogren syndrome graft versus host disease, chemical injuries, dry eyes, limbal stem cell deficiency, ocular cicatricial pemphigoid, exposure keratitis and toxic epidermal necrolysis. ${ }^{33}$ The limitation of the use of scleral lenses is high cost, reduced tear exchange and difficult insertion-removal, which requires considerable practice. ${ }^{28} 32-34$ Table 2 summarises the outcome of these lenses in cases with corneal ectasias. Overall, studies have shown a good outcome with these lenses. ${ }^{28} 29-34$

\section{Surgical management}

Most cases with ACE require surgery for visual rehabilitation as well as for improving corneal strength. Cases with corneal perforation require urgent surgical intervention. Prophylactic surgery is indicated in cases with TMD when perforation is imminent due to extreme thinning. ${ }^{10} 20$

There are many challenges in the surgical management of ACE. First, due to the involvement of the paracentral and peripheral cornea, a large graft with increased proximity to the limbus is often required which increases the chances of graft rejection. Second, extreme corneal thinning extending over a very wide area makes suturing difficult and increases the chances of intraoperative DM perforation. Moreover, recurrence of the original disease can complicate the long-term outcome. $^{35} 36$ Lastly, all these procedures are technically difficult with a steep learning curve. ${ }^{20}$

\section{Intrastromal corneal ring segment}

Intrastromal corneal ring segment (ICRS) is a method of improving CL tolerance and best-corrected VA for patients with corneal ectasia having a clear cornea. ${ }^{37}$ ICRS are commonly indicated for cases with moderate keratoconus. Recently, Intacs SK (SK-severe keratoconus) has been introduced for use in more severe forms of corneal ectasia. It has two significant design modifications-a smaller inner diameter of $6.0 \mathrm{~mm}$ compared with $6.8 \mathrm{~mm}$ of the standard Intacs; and an elliptical cross section compared with a hexagonal cross section of the standard Intacs. ${ }^{38}$ Since their introduction ICRS have been used in cases of ACE with favourable outcomes (table 3) and without any significant complications. ${ }^{37-42}$

\section{Large diameter penetrating keratoplasty}

A conventional large diameter PKP is performed in cases with ACE so as to include the thinned out periphery. ${ }^{43} 44$ In cases with PMD large eccentric PKP has been described. ${ }^{43}$ The problems with such a graft is an increased risk of rejection due to proximity to the limbus. A decentred graft can induce severe postoperative astigmatism and higher incidence of rejection, because of proximity to the limbus (table 3 ). ${ }^{43} 44$

\section{Lamellar keratoplasty}

Crescentic lamellar keratoplasty $(L K)$ is a surgical technique where a crescentic corneal transplant is performed to reinforce the area of thinning. It is one of the earliest surgical procedures reported by Schanzlin et $a l^{58}$ Few case reports have described the use of this technique in management of spontaneous perforation in cases of PMD. ${ }^{59}$ Compressive C-shaped $L K$ is a peripheral LK technique described by Cheng et $a l^{45}$ in cases with PMD/TMD. A 'match and patch' lamellar graft procedure is performed. Precise dissection of the lamellar recipient bed is done to achieve vertical margins and an even stromal bed depth. A lamellar donor undersized by $0.25-0.5 \mathrm{~mm}$ is then sutured to the recipient bed. Suturing a narrower donor onto a wider recipient bed results in flattening and reduction of ectasia. ${ }^{45}$ Modified deep lamellar keratoplasty is a technique described by Shi et $a l^{46}$ where the initial four-fifths of the corneal lamellae

Table 2 Outcome of various contact lenses in advanced corneal ectasia

\begin{tabular}{|c|c|c|c|c|c|}
\hline Author & Type of CL & Type of study & Indications & Sample size & Outcome \\
\hline Gupta et $a l^{29}$ & ROSE K versus Soper lenses & $\begin{array}{l}\text { Randomised control } \\
\text { trial }\end{array}$ & Keratoconus & $n=60$ & $\begin{array}{l}\text { ROSE K cases; significantly better glare } \\
\text { acuity and contrast sensitivity } \\
\text { BCLCVA-no significant difference }\end{array}$ \\
\hline $\begin{array}{l}\text { Fernandez- } \\
\text { Velazquez }\end{array}$ & Kerasoft IC versus ROSE $\mathrm{K}$ & Retrospective & Keratoconus PMD & $\begin{array}{l}\mathrm{n}_{1}=94(\mathrm{KC}) \\
\mathrm{n}_{2}=77(\text { ROSE K) }\end{array}$ & BCLCVA-no significant difference \\
\hline Baran et $a l^{31}$ & PROSE & Retrospective & Corneal ectasia & $n=59$ & $\begin{array}{l}\text { Satisfactory fit and significant improvement } \\
\text { in visual acuity }\end{array}$ \\
\hline Lee et $a l^{34}$ & PROSE & Retrospective & $\begin{array}{l}\text { Keratoconus } \\
\text { Post-PKP }\end{array}$ & $\begin{array}{l}\mathrm{n}_{1}=25 \\
\mathrm{n}_{2}=18\end{array}$ & $\begin{array}{l}\text { Improvement in visual acuity }-88 \% \text { and } \\
\text { OSDI score }-79 \% \text { of cases }\end{array}$ \\
\hline Rathi et $a l^{33}$ & BOSP & Retrospective & $\begin{array}{l}\text { RGP lenses failure and } \\
\text { cases of corneal ectasia }\end{array}$ & $n=23$ & Significant improvement in visual acuity \\
\hline
\end{tabular}

BCLCVA, best contact lens corrected visual acuity; BOSP, Boston ocular surface prosthesis; CL, contact lenses; KC, keratoconus; OSDI, Ocular Surface Disease Index; PKP, penetrating keratoplasty; PMD, pellucid marginal degeneration; PROSE, prosthetic replacement of ocular surface ecosystem; RGP, rigid gas permeable. 
Table 3 Outcome of various surgical techniques in advanced corneal ectasia

\begin{tabular}{|c|c|c|c|c|c|c|}
\hline Author & Surgery & Type of study & $\mathrm{N}$ & Indication & Outcome & Complications \\
\hline Rodriguez et $a l^{39}$ & Intacs SK & $\begin{array}{l}\text { Retrospective longitudinal } \\
\text { case series }\end{array}$ & 6 & $\begin{array}{l}\text { Post-LASIK advanced } \\
\text { ectasia }\end{array}$ & $\begin{array}{l}\text { Average } \mathrm{Km} \text { reduced from } 53.80 \\
\pm 6.30 \mathrm{D} \text { to } 48.57 \pm 5.00 \mathrm{D}\end{array}$ & $\begin{array}{l}\text { No significant } \\
\text { complications }\end{array}$ \\
\hline Khan et $a l^{40}$ & Intacs SK & Case series & 31 & $\begin{array}{l}\text { Moderate to severe } \\
\text { keratoconus }\end{array}$ & $\begin{array}{l}\text { Average } \mathrm{Km} \text { reduced from } \\
52.07 \mathrm{D} \text { to } 46.15 \mathrm{D} \text { for } \mathrm{K} 1 \text { and } \\
\text { from } 57.9 \mathrm{D} \text { to } 51.2 \mathrm{D} \text { for } \mathrm{K} 2\end{array}$ & Segment extrusion \\
\hline $\begin{array}{l}\text { Sansanayudh } \\
\text { et } a l^{41}\end{array}$ & Intacs SK & $\begin{array}{l}\text { Retrospective } \\
\text { non-randomised study }\end{array}$ & 10 & Advanced keratoconus & $\begin{array}{l}\text { Significant improvement in visual } \\
\text { and aberrometric outcome }\end{array}$ & $\begin{array}{l}\text { No significant } \\
\text { complications }\end{array}$ \\
\hline Fahd et $a l^{42}$ & Intacs SK & Case series & 24 & $\begin{array}{l}\text { Moderate to severe } \\
\text { keratoconus }\end{array}$ & $\begin{array}{l}\text { Reduction in myopia and } \\
\text { astigmatism Improvement in } \\
\text { BCVA Average } \mathrm{Km} \text { of } 52.03 \\
\pm 4.49 \text { D }\end{array}$ & $\begin{array}{l}\text { No significant } \\
\text { complication }\end{array}$ \\
\hline $\begin{array}{l}\text { Kotb and } \\
\text { Hantera }^{38}\end{array}$ & Intacs SK & $\begin{array}{l}\text { Prospective, } \\
\text { non-comparative }\end{array}$ & 37 & $\begin{array}{l}\text { Keratoconus, Krumeich's } \\
\text { stage II-31 eyes, } \\
\text { Krumeich's stage III-6 } \\
\text { eyes }\end{array}$ & $\begin{array}{l}\text { Significant improvement in UCVA } \\
\text { at } 6 \text { months }\end{array}$ & $\begin{array}{l}\text { Bullous keratopathy } \\
\text { Overlapping of distal } \\
\text { end of ICRS }\end{array}$ \\
\hline Varley et $a l^{43}$ & Large diameter PKP & $\begin{array}{l}\text { Prospective } \\
\text { non-comparative }\end{array}$ & 11 & PMD & $\begin{array}{l}\text { Mean BCVA } 20 / 30 \\
\text { Average keratometric astigmatism } \\
-2.46 \text { D }\end{array}$ & $\begin{array}{l}\text { Graft failure } \\
\text { Retinal detachment } \\
\text { Bacterial corneal } \\
\text { ulcer }\end{array}$ \\
\hline Speaker et $a l^{44}$ & Large diameter PKP & Case series & 15 & Keratoconus and PMD & $1 \mathrm{graft}$ failure & 9/5 graft rejection \\
\hline Cheng et $a l^{45}$ & Compressive C-shaped LK & $\begin{array}{l}\text { Retrospective, } \\
\text { non-comparative, } \\
\text { interventional case series }\end{array}$ & 4 & $\mathrm{PMD} / \mathrm{TMD}$ & $\begin{array}{l}\text { No recurrence } \\
\text { Stable astigmatism ranging from } \\
0 D \text { to }-2.75 D \\
B C V A \geq 20 / 40\end{array}$ & Cataract progression \\
\hline Shi et $a l^{46}$ & Modified deep LK & Prospective & 65 & Keratoconus (K> $60 \mathrm{D})$ & $\begin{array}{l}\text { No detectable corneal graft } \\
\text { rejection } \\
\text { Average BCVA-20/25 at } 1 \text { year }\end{array}$ & $\begin{array}{l}\text { Interface fluid-9 } \\
\text { cases }\end{array}$ \\
\hline $\begin{array}{l}\text { Rasheed and } \\
\text { Rabinowitz }\end{array}$ & Simultaneous LK with PKP & $\begin{array}{l}\text { Retrospective, } \\
\text { interventional case series }\end{array}$ & 5 & PMD & $\begin{array}{l}\text { No graft rejection } \\
\text { BCVA } \geq 20 / 40\end{array}$ & $\begin{array}{l}\text { Increased IOP } \\
\text { PSC }\end{array}$ \\
\hline $\begin{array}{l}\text { Jones and } \\
\text { Kirkness }{ }^{48}\end{array}$ & $\begin{array}{l}\text { LK followed by secondary } \\
\text { PKP }\end{array}$ & Case report & 2 & Keratoglobus & $\begin{array}{l}\text { The right and left eye BCVA } 6 / 60 \\
\text { and } 6 / 18 \text {, respectively }\end{array}$ & $\begin{array}{l}\text { Right eye graft } \\
\text { decompensation }\end{array}$ \\
\hline Vajpayee et al ${ }^{49}$ & 'Tuck in' LK & Retrospective & 4 & Post-PKP corneal ectasia & $\begin{array}{l}\text { Mean } \mathrm{Km} \text { decreased from } \\
59.67 \mathrm{D} \text { to } 43.50 \mathrm{D} \text {, Significant } \\
\text { improvement of BCVA from mean } \\
\text { of } 0.05 \text { to } 0.34\end{array}$ & $\begin{array}{l}\text { No significant } \\
\text { complication }\end{array}$ \\
\hline Kaushal et $a l^{50}$ & 'Tuck in' LK & $\begin{array}{l}\text { Prospective interventional } \\
\text { case series }\end{array}$ & 12 & $\begin{array}{l}\text { Keratoconus with PMD } \\
(n=8) \text { Keratoglobus }(n=4)\end{array}$ & $\begin{array}{l}\text { All patients had BCVA }>20 / 80 \\
\text { Mean } \mathrm{Km} \text { decreased from } \\
57.54 \mathrm{D} \text { to } 46.36 \mathrm{D} \text {, Mean } \\
\text { spherical equivalent decreased } \\
\text { from }-7.8 \mathrm{D} \text { to } 1.23 \mathrm{D}\end{array}$ & $\begin{array}{l}\text { No significant } \\
\text { complication }\end{array}$ \\
\hline Busin et $a l^{51}$ & $\begin{array}{l}\text { Tissue excision and corneal } \\
\text { tuck }\end{array}$ & $\begin{array}{l}\text { Prospective interventional } \\
\text { case series }\end{array}$ & 3 & Extremely advanced PMD & $\begin{array}{l}\text { Stable resolution of the ectasia in } \\
\text { all cases } \\
\text { BCVA-20/30 to } 20 / 50\end{array}$ & $\begin{array}{l}\text { No significant } \\
\text { complication }\end{array}$ \\
\hline $\begin{array}{l}\text { Reinhard and } \\
\text { Sundmacher }\end{array}$ & Sclerokeratoplasty & Case report & 2 & $\begin{array}{l}\text { Keratoconus with } \\
\text { peripheral ectasia }\end{array}$ & $\begin{array}{l}\text { Better contact lens fitting } \\
\text { Improvement in BCVA }\end{array}$ & $\begin{array}{l}\text { No significant } \\
\text { complication }\end{array}$ \\
\hline $\begin{array}{l}\text { Kanellopulous } \\
\text { and } \mathrm{Pe}^{53}\end{array}$ & Corneoscleroplasty & Case report & 1 & Keratoglobus & BCVA 20/50 & $\begin{array}{l}\text { No significant } \\
\text { complication }\end{array}$ \\
\hline $\begin{array}{l}\text { Maccheron and } \\
\text { Daya }^{54}\end{array}$ & Wedge resection & Retrospective & 7 & PMD & $\begin{array}{l}\text { Average reduction in keratometric } \\
\text { cylinder of } 9.1 \mathrm{D} \\
\text { Improved UCVA, BCVA, } \\
\text { keratometric cylinder, and } \\
\text { spectacle or CL tolerance }\end{array}$ & $\begin{array}{l}\text { No significant } \\
\text { complication }\end{array}$ \\
\hline Busin et $a l^{55}$ & $\begin{array}{l}\text { Combined wedge resection } \\
\text { and bevelled penetrating } \\
\text { relaxing incisions }\end{array}$ & $\begin{array}{l}\text { Prospective, } \\
\text { non-comparative, } \\
\text { interventional case series }\end{array}$ & 10 & PMD & $\begin{array}{l}\text { BCVA } \geq 20 / 40 \text { in } 8 \text { of } 10 \text { cases } \\
\text { Keratometric astigmatism } \\
\text { reduced from } 15.1 \mathrm{D} \\
\text { preoperatively to } 4.6 \mathrm{D} \\
\text { postoperatively }\end{array}$ & $\begin{array}{l}\text { No significant } \\
\text { complication }\end{array}$ \\
\hline Cameron $^{56}$ & Lamellar crescentic resection & Prospective & 5 & PMD & $\begin{array}{l}\text { BCVA } \geq 20 / 40 \text { in four of the five } \\
\text { eyes. }\end{array}$ & $\begin{array}{l}\text { Inferior pannus, } \\
\text { loose sutures, } \\
\text { Recurrence }\end{array}$ \\
\hline Javadi et $a l^{57}$ & Lamellar crescentic resection & Prospective & 15 & PMD & $\begin{array}{l}\text { BCVA of } 20 / 40 \text { in } 71 \% \text { of cases } \\
\text { Mean astigmatism of } 16.00 \text { D at } \\
6 \text { weeks and } 4.30 \text { D } 2 \text { years } \\
\text { postoperatively }\end{array}$ & $\begin{array}{l}\text { No significant } \\
\text { complication }\end{array}$ \\
\hline
\end{tabular}

BCVA, best corrected visual acuity; CL, contact lenses; ICRS, intrastromal corneal ring segment; IOP, intraocular pressure; Km, keratometric reading; LASIK, laser in situ keratomileusis; LK, lamellar keratoplasty; PKP, penetrating keratoplasty; PMD, pellucid marginal degeneration; PSC, posterior subcapsular cataract; SK, severe keratoconus; TMD, Terrien's marginal degeneration; UCVA, uncorrected visual acuity. 
(diameter of $7.75 \mathrm{~mm}$ ) are removed using a vacuum trephine followed by lamellar stromal dissection with a diamond knife leaving $2 \mathrm{~mm}$ (in diameter) of DM at the top of the cone. A corneal graft $(8.0 \mathrm{~mm}$ in diameter $)$ is then sutured to the recipient.

\section{Lamellar keratoplasty with penetrating keratoplasty}

PKP has the advantage of excellent visual outcome but the disadvantages are the need for a large graft, proximity of the graft to the limbus and high post-PKP astigmatism. LK has the advantage of providing tectonic support and preserving the host endothelium but, interface haze and quality of vision is a concern. Several authors have attempted to combine both the procedures so that a large diameter lamellar graft can provide tectonic support to the weakened peripheral host cornea while a central small diameter full thickness graft can provide excellent VA. $^{47} 6061$

Simultaneous peripheral crescentic $L K$ and central PKP: LK is followed by central PKP. ${ }^{47}$ The lamellar transplant restores normal thickness to the peripheral thinned cornea and enables good edge-to-edge apposition at the time of PKP. This reduces the risk of high post-PKP astigmatism and allows for selective suture removal and astigmatic keratotomy to reduce any residual astigmatism. The advantage is, performing the two procedures in the same sitting helps avoid the need for two separate corneas as in cases of sequential LK followed by PKP. The limitation of this surgery is its technical difficulty.

Tectonic LK followed by secondary PKP: A tectonic LK is followed by a secondary PKP usually after 6 months. ${ }^{61}$ In this technique, the host cornea is first trephined to the depth of the anterior stroma within the limbus. The lamellar dissection technique is used for tunnelling into the sclera under the limbus to preserve stem cells. The host corneal epithelium is completely debrided, and a donor corneoscleral button, denuded of its endothelium, is sutured on top of it with interrupted sutures. Six months later, a central PKP is performed. ${ }^{48}$

\section{'Tuck in' lamellar keratoplasty}

'Tuck in' LK is a special technique of LK for cases of advanced peripheral corneal-thinning disorders like PMD, keratoglobus, or cases with a combination of keratoconus and PMD. ${ }^{50} 49$ The surgery involves central anterior stromal lamellar resection followed by creation of a peripheral intrastromal pocket circumferentially in the corneal periphery up to a point $0.5 \mathrm{~mm}$ away from the limbus. The donor tissue is prepared such that it has a central full-thickness graft with a peripheral partial-thickness flange of about $2.5-3 \mathrm{~mm}$. The flange of the donor lenticule is tucked into the intrastromal pocket of the host and the graft is sutured to the host. In cases of PMD, only an inferior $180^{\circ}$ tucking is done. The central full-thickness graft provides tectonic support to the central cornea while the thin peripheral flange tucked into the intrastromal pocket integrates into the host and provides tectonic support to the peripheral cornea. Moreover, there is no damage to the recipient's limbal stem cells as dissection of the limbal region is avoided, which subsequently promotes healing of the epithelium at the graft-host junction. Combined tissue excision and corneal tuck was described by Busin et $a l^{51}$ in advanced PMD where partial excision of the ectatic part and tucking of the residual thinned corneal lips is done.

\section{Corneoscleroplasty}

Lamellar horseshoe-shaped sclerokeratoplasty is a technique where a large 14-mm corneoscleral lamellar allograft is done to support corneal thinning and scleral thinning. ${ }^{52}$ Kanellopolous and $\mathrm{Pe}^{53}$ reported the use of a corneoscleral rim over the thinned corneal periphery of a patient with keratoglobus that acted as a buttress while avoiding any manipulation of the central visual area.

\section{Wedge resection}

When ectasia is confined to a small sector of the periphery a wedge resection can be performed to reduce astigmatism. ${ }^{62-64}$ This technique has several advantages over a corneal graft: preservation of normal central cornea, no risk of rejection or interface haze, better wound strength and shorter visual rehabilitation period. ${ }^{62-64}$ However, postoperative unstable astigmatism is an issue due to persistent tension at the sutured wound. Various modifications have been described to improve the outcome of wedge resection. Maccheron and Daya ${ }^{54}$ have reported wedge resection followed by complete (limbus to limbus) or partial host deep lamellar dissection to enable closure by mobilising the host anterior lamellar cornea for cases of PMD. Busin et $a l^{55}$ have reported corneal wedge resection combined with paired, opposed clear corneal penetrating relaxing incisions for the treatment of PMD. After crescent-shaped wedge excision of the thinned area inferiorly, the anterior chamber is filled with viscoelastic, and a $3.2-\mathrm{mm}$ metal keratome is used to create two bevelled, penetrating, clear-corneal keratotomies, one at each of the topographic steep axes, immediately anterior to the limbus. The relaxing incisions prevent the astigmatic drift seen following wedge resection. ${ }^{55}$ Lamellar crescentic resection is similar to wedge resection where the inferior thinned area is excised followed by reapposition of normalthickness stroma with multiple interrupted $10-0$ polypropylene sutures. $^{5657}$

Outcomes: Table 3 summarises the outcome of these procedures. $^{43-64}$

\section{PREVENTION OF ADVANCED ECTASIA Collagen cross linking}

Ultraviolet-A/riboflavin-mediated collagen cross linking (CXL) increases the biomechanical strength of the cornea through the formation cross links between collagen fibres. CXL is done mostly in early cases of corneal ectasia with a central corneal thickness $>400$ microns. Recently CXL has been reported in thinner corneas with modifications such as the use of a hypo-osmolar riboflavin solution. ${ }^{65-68}$ However, at present the evidence regarding the efficacy and safety of CXL in thin corneas, is limited.

\section{Mid-stromal isolated Bowman layer transplantation}

This is a new surgical technique to reduce and stabilise ectasia in eyes with advanced keratoconus. Mid-stromal transplantation of an isolated Bowman layer graft leads to stabilisation of ectasia by the Bowman layer itself, as well as through the woundhealing effect between the host stroma and the Bowman layer graft. $^{69} 70$ In this technique an isolated Bowman layer 9.0$11.0-\mathrm{mm}$ in diameter is dissected from the anterior stroma over $360^{\circ}$ using a McPherson forceps and a custom-made stripper. This Bowman roll is submerged in $70 \%$ ethanol to remove remnant epithelial cells. A mid-stromal pocket up to the limbus over $360^{\circ}$ is created under air using the manual dissection technique. The Bowman roll is inserted into the stromal pocket using a special glide. Then it is unfolded and centred by manipulating the graft with a cannula and a balanced salt solution. Van Dijk et al have reported reduction and stabilisation of corneal ectasia in two published series (one study involving 20 
eyes and the other involving 10 eyes of progressive, advanced keratoconus) following successful mid-stromal isolated Bowman layer transplantation. ${ }^{69} 70$ The same author further evaluated the role of this technique to stabilise ectasia, to postpone surgery and to enable continued daily CL wear, in 22 eyes with advanced keratoconus. ${ }^{71}$ Reduction and stabilisation of corneal ectasia could be achieved in 20 eyes with this technique. Two surgeries were complicated by an intraoperative perforation of DM. Thus early results, using this new technique, are encouraging. However, long-term studies are needed to establish the safety and efficacy of this procedure. At this point it can be said Bowman layer transplantation could become a supplementary treatment option in the management of advanced keratoconus to postpone PK or DALK and to minimise the risk of long-term complications. ${ }^{69-71}$

\section{CONCLUSIONS}

Management of advanced corneal ectasia is a challenge for any corneal surgeon. Over the last decade a number of new surgical techniques have evolved with variable success. The evidence supporting the safety and efficacy of these techniques is inadequate but these techniques are extremely helpful in difficult cases. Prevention of progression at an early stage of disease is the best way to deal with these disorders. Modifications in collagen cross linking and mid-stromal transplantation of Bowman layer may be promising tools for prevention of such disorders in future.

Twitter Follow Prafulla Maharana at @praful276 and Rasik Vajpayee at @rasiikv

Contributors Concept and design: RBV. Writing of the manuscript: PKM, AD and VJ. Critical revision and final approval: PKM, AD, VJ, SD, NS and RBV.

Competing interests None declared.

Provenance and peer review Not commissioned; externally peer reviewed.

\section{REFERENCES}

1 Sharma N, Maharana PK, Jhanji V, et al. Management of acute corneal hydrops in ectatic corneal disorders. Curr Opin Ophthalmol 2012;23:317-23.

2 Vajpayee RB, Bhartiya P, Sharma N. Central lamellar keratoplasty with peripheral intralamellar tuck: a new surgical technique for keratoglobus. Cornea 2002;21:657-60.

3 Tan BU, Purcell TL, Torres LF, et al. New surgical approaches to the management of keratoconus and post-lasik ectasia. Trans Am Ophthalmol Soc 2006;104:212-20.

4 Jhanji V, Sharma N, Vajpayee RB. Management of keratoconus: current scenario. Br J Ophthalmol 2011;95:1044-50.

5 Tan DT, Por YM. Current treatment options for corneal ectasia. Curr Opin Ophthalmol 2007;18:284-9.

6 Ishii R, Kamiya K, Igarashi A, et al. Correlation of corneal elevation with severity of keratoconus by means of anterior and posterior topographic analysis. Cornea 2012;31:253-8.

7 Buxton JN, Buxton DF, Dias AK, et al. Keratoconus Basic and Clinical Features. The CLAO Guide to Basic Science and Clinical Practice. 3rd edn. Vol. 3. lowa: Kendall/ Hunt, 1995:101-22.

8 Krachmer JH, Feder RS, Belin MW. Keratoconus and related non inflammatory corneal thinning disorders. Surv Ophthalmol 1984;28:293-322.

9 Sridhar MS, Mahesh S, Bansal AK, et al. Pellucid marginal corneal degeneration. Ophthalmology 2004;111:1102-10.

10 Beauchamp GR. Terrien's marginal corneal degeneration. J Pediatr Ophthalmol Strabismus 1982;19:97-9.

11 Wallang BS, Das S. Keratoglobus. Eye 2013;27:1004-12.

12 Binder PS. Ectasia after laser in situ keratomileusis. J Cataract Refract Surg 2003:29:2419-29.

13 Randleman JB, Russell B, Ward MA, et al. Risk factors and prognosis for corneal ectasia after LASIK. Ophthalmology 2003;110:267-75.

14 Winkle RK, Mader TH, Parmley VC, et al. The etiology of refractive changes at high altitude after radial keratotomy: Hypoxia versus hypobaria. Ophthalmology 1998;105:282-6

15 Leccisotti A. Corneal ectasia after photorefractive keratectomy. Graefes Arch Clin Exp Ophthalmol 2007;245:869-75

16 Pramanik S, Musch DC, Sutphin JE, et al. Extended long-term outcomes of penetrating keratoplasty for keratoconus. Ophthalmology 2006;113:1633-8.
17 Feizi S, Javadi MA, Rezaei Kanavi M. Recurrent keratoconus in a corneal graft after deep anterior lamellar keratoplasty. J Ophthalmic Vis Res 2012;7:328-31.

18 Kymionis $G$, Bouzoukis $D$, Diakonis $V$, et al. Long term results of thin corneas after refractive laser surgery. Am J Ophthalmol 2007;144:181-5.

19 Twa MD, Nichols JJ, Joslin CE, et al. Characteristics of corneal ectasia after LASIK for myopia. Cornea 2004;23:447-57.

20 Feder RS, Gan TJ. Non inflammatory ectatic disorders. In: Krachmer JH, Mannis MJ, Holland EJ, eds. Cornea. 3rd edn. St. Louis, MO: Mosby, 2011:865-78.

21 Faramarzi A, Ziai H. Central corneal thickness measurement by ultrasound versus orbscan II. J Ophthalmic Vis Res 2008;2:83-6.

22 Cairns G, McGhee CN. Orbscan computerized topography: attributes, applications, and limitations. J Cataract Refract Surg 2005;31:205-20.

23 Belin MW, Ambrosio R. Scheimpflug imaging for keratoconus and ectatic disease. Indian I Ophthalmol 2013;61:401-6.

24 Jhanji V, Yang B, Yu M, et al. Corneal thickness and elevation measurements using swept-source optical coherence tomography and slit scanning topography in norma and keratoconic eyes. Clin Experiment Ophthalmol 2013;41:735-45.

25 Jhanji V, Constantinou M, Beltz J, et al. Evaluation of posterior wound profile after penetrating keratoplasty using anterior segment optical coherence tomography. Cornea 2011;30:277-80

26 Maharana PK, Sharma N, Vajpayee RB. Acute corneal hydrops in keratoconus. Indian I Ophthalmol 2013;61:461-4.

27 Vajpayee RB, Maharana PK, Kaweri L, et al. Intrastromal fluid drainage with air tamponade: anterior segment optical coherence tomography guided technique for the management of acute corneal hydrops. Br J Ophthalmol 2013;97:834-6.

28 Rathi VM, Mandathara PS, Dumpati S. Contact lens in keratoconus. Indian J Ophthalmol 2013;61:410-5.

29 Gupta R, Sinha R, Singh P, et al. Rose-K versus Soper contact lens in keratoconus: a randomized comparative trial. Middle East Afr J Ophthalmol 2014;21:50-5.

30 Fernandez-Velazquez FJ. Kerasoft IC compared to Rose-K in the management of corneal ectasias. Cont Lens Anterior Eye 2012;35:175-9.

31 Baran I, Bradley JA, Alipour F, et al. PROSE treatment of corneal ectasia. Cont Lens Anterior Eye 2012;35:222-7.

32 Jimenez RM, Rodriguez FP. Utility of a semi-scleral contact lens design in the management of the irregular cornea. Cont Lens Anterior Eye 2013;36:146-50.

33 Rathi VM, Mandathara PS, Dumpati S, et al. Boston ocular surface prosthesis: An Indian experience. Indian J Ophthalmol 2011;59:279-81.

34 Lee JC, Chiu GB, Bach D, et al. Functional and visual improvement with prosthetic replacement of the ocular surface ecosystem scleral lenses for irregular corneas. Cornea 2013;32:1540-3.

35 Bourges JL, Savoldelli M, Dighiero P, et al. Recurrence of keratoconus characteristics: a clinical and histologic follow-up analysis of donor grafts. Ophthalmology 2003;110:1920-5.

36 Bechrakis N, Blom ML, Stark WJ, et al. Recurrent keratoconus. Cornea 1994;13:73-7.

37 Pinero DP, Alio JL, Kady B, et al. Refractive and aberrometric outcomes of intracorneal ring segments for keratoconus: mechanical versus femtosecond-assisted procedures. Ophthalmology 2009:116:1675-87.

38 Kotb AM, Hantera M. Efficacy and safety of Intacs SK in moderate to severe keratoconus. Middle East Afr J Ophthalmol 2013;20:46-50.

39 Rodriguez, Luis A, Porras AE, et al Treatment of six cases of advanced ectasia after LASIK with 6-mm intacs SK. J Refract Surg 2009;25:1116-19.

40 Khan Ml, Injarie A, Muhtaseb M. Intrastromal corneal ring segments for advanced keratoconus and cases with high keratometric asymmetry. I Cataract Refract Surg 2012:38:129-36

41 Sansanayudh W, Bahar I, Kumar NL, et al. Intrastromal corneal ring segment SK implantation for moderate to severe keratoconus. I Cataract Refract Surg 2010;36:110-13

42 Fahd DC, Jabbur NS, Awwad ST. Intrastromal corneal ring segment SK for moderate to severe keratoconus: a case series. J Refract Surg 2012;28:701-5.

43 Varley GA, Macsai MS, Krachmer JH. The results of penetrating keratoplasty for pellucid marginal corneal degeneration. Am J Ophthalmol 1990;110:149-52.

44 Speaker MG, Arentsen JJ, Laibson PR. Long-term survival of large diameter penetrating keratoplasties for keratoconus and pellucid marginal degeneration. Acta Ophthalmol Suppl 1989;192:17-9.

45 Cheng CL, Theng JT, Tan DT. Compressive C-shaped lamellar keratoplasty: a surgical alternative for the management of severe astigmatism from peripheral corneal degeneration. Ophthalmology 2005;112:425-30.

46 Shi W, Li S, Gao H, et al. Modified deep Lamellar Keratoplasty for the treatment of advanced-stage Keratoconus with steep curvature. Ophthalmology 2010;117:226-31.

47 Rasheed K, Rabinowitz YS. Surgical treatment of advanced pellucid marginal degeneration. Ophthalmology 2000;107:1836-40.

48 Jones DH, Kirkness CM. A new surgical technique for keratoglobus-tectonic lamellar keratoplasty followed by secondary penetrating keratoplasty. Cornea 2001;20:885-7.

49 Vajpayee RB, Jhanji V, Beltz J, et al. "Tuck In" Lamellar Keratoplasty for tectonic management of post keratoplasty corneal ectasia with peripheral corneal involvement. Cornea 2011;30:171-4. 
50 Kaushal S, Jhanji V, Sharma N, et al. Tuck In Lamellar Keratoplasty (TILK) for corneal ectasias involving corneal periphery. Br J Ophthalmol 2008;92:286-90.

51 Busin M, Santorum P, Barbara R, et al. Combined tissue excision and corneal tuck for the surgical treatment of extremely advanced pellucid marginal corneal degeneration. Cornea 2013;32:1628-30.

52 Reinhard T, Sundmacher R. Lamellar horseshoe sclerokeratoplasty and thermoplasty in keratoconus with peripheral ectasia of the cornea. Klin Monatsbl Augenheilkd 1994;205:305-8.

53 Kanellopolous AJ, Pe LH. An alternative surgical procedure for the management of keratoglobus. Cornea 2005;24:1024-6.

54 Maccheron LJ, Daya SM. Wedge resection and lamellar dissection for pellucid marginal degeneration. Cornea 2012;31:708-15.

55 Busin M, Kerdraon Y, Scorcia V, et al. Combined wedge resection and beveled penetrating relaxing incisions for the treatment of pellucid marginal corneal degeneration. Cornea 2008;27:595-600.

56 Cameron JA. Results of lamellar crescentic resection for pellucid marginal corneal degeneration. Am J Ophthalmol 1992;113:296-302.

57 Javadi MA, Karimian F, Hosseinzadeh A, et al. Lamellar crescentic resection for pellucid marginal corneal degeneration. J Refract Surg 2004;20:162.

58 Schanzlin DJ, Sarno EM, Robin J. Crescentic lamellar keratoplasty for pellucid marginal degeneration. Am J Ophthalmol 1983;96:253-4.

59 Symes RJ, Catt CJ, Sangiampornpanit T, et al. Corneal perforation associated with pellucid marginal degeneration and treatment with crescentic lamellar keratoplasty: two case reports. Cornea 2007;26:625-8.

60 Kremer I, Sperber LT, Laibson PR. Pellucid marginal degeneration treated by lamellar and penetrating keratoplasty. Arch Ophthalmol 1993;111:169-70.
61 Lake D, Hamada S, Khan S, et al. Deep anterior lamellar keratoplasty over penetrating keratoplasty for host rim thinning and ectasia. Cornea 2009;28:489-92.

62 Ilari L, Daya SM. Corneal wedge resection to treat progressive keratoconus in the host cornea after penetrating keratoplasty. I Cataract Refract Surg 2003:29:395-401.

63 Biswas S, Brahma A, Tromans C, et al. Management of pellucid marginal corneal degeneration. Eye(Lond) 2000;14:629-34.

64 MacLean H, Robinson LP, Wechsler AW. Long-term results of corneal wedge resection for pellucid marginal degeneration. Eye(Lond) 1997;11:613-17.

65 Raiskup F, Spoerl E. Corneal cross-linking with hypo-osmolar riboflavin solution in thin keratoconic corneas. Am J Ophthalmol 2011;152:28-32.

66 Sloot $F$, Soeters $N$, van der Valk $R$, et al. Effective corneal collagen crosslinking in advanced cases of progressive keratoconus. J Cataract Refract Surg 2013;39:1141-5.

67 Hafezi F, Mrochen M, Iseli HP, et al. Collagen crosslinking with ultraviolet-A and hypoosmolar riboflavin solution in thin corneas. I Cataract Refract Surg 2009:35:621-4.

68 Ivarsen A, Hjortdal J. Collagen cross-linking for advanced progressive keratoconus. Cornea 2013;32:903-6.

69 Van DK, Liarakos VS, Parker J, et al. Bowman layer transplantation to reduce and stabilize progressive, advanced Keratoconus. Ophthalmology 2015;14:161-4.

70 Van DK, Parker J, Tong CM, et al. Midstromal isolated Bowman layer graft for reduction of advanced keratoconus: a technique to postpone penetrating or deep anterior lamellar keratoplasty. JAMA Ophthalmol 2014;132:495-501.

71 Van Dijk K, Liarakos VS, Parker J, et al. Bowman layer transplantation to reduce and stabilize progressive, advanced keratoconus. Ophthalmology 2015;122:909-17. 